Research Article

\title{
Considerations on Green Public Procurement of Coaches
}

\author{
Ionel PREDA and Doina I. POPESCU
}

The Bucharest University of Economic Studies, Bucharest, Romania

Correspondence should be addressed to: Doina I. POPESCU; doinaipopescu@yahoo.com

Received date:27 February 2019; Accepted date:3 May 2019; Published date: 23 August 2019

Academic Editor: Jolanta Baran

Copyright @ 2019. Ionel PREDA and Doina I. POPESCU. Distributed under Creative Commons CC-BY 4.0

\begin{abstract}
The paper analyzes the features of green public procurement of coaches in Romania. The paper presents a model of a process of preparing the green procurement procedure in order to determine the award criteria. In the presented model, purchase prices need to be estimated and life cycle costs have to be calculated for the most representative types of coaches on the Romanian market. Through this study we aim to identify the relevant award criterion for the considered coaches.
\end{abstract}

Keywords: green public procurement, cost-per-life cycle, coach, purchase price.

\section{Introduction}

Green public procurement (GPP) aims to improve the economic sustainability and the environment.

Green public procurement is defined by the European Commission (2016b) as: "a process whereby public authorities seek to procure goods, services and works with a reduced environmental impact throughout their life cycle when compared to goods, services and works with the same primary function that would otherwise be procured ".
Public procurement is increasingly perceived as a means of improving sustainability. The United Nations Sustainable Development Agenda 2030 explicitly refers to the need of promoting sustainable procurement as a goal of sustainable development (UN, 2015).

Even if green public procurement has higher purchase prices, green products can help reduce costs. The European Commission (2016a) has considered green procurement as a way to save money, when costs are analysed from the life-cycle perspective, for

Cite this Article as: Ionel PREDA and Doina I. POPESCU (2019)," Considerations on Green Public Procurement of Coaches", Journal of Eastern Europe Research in Business and Economics Vol. 2019 (2019), Article ID 139043, DOI: 10.5171/2019.139043 
example through saved materials and energy, reduction of waste and pollution.

Green public procurement leads to the acquisition of "green", ecological products, whose environmental impact over the entire life cycle is lower compared to other comparable products or solutions (Ghisetti, 2017).

In other words, organizations have to choose products or services that are "healthier" or more "environmentally friendly", promoting recycling, "green" buildings that operate with low energy (less polluting) and sustainable consumption (Buniamin et al., 2016).

Making decisions about purchasing green products requires clear, easy-to-understand assessment methods. Life Cycle Assessment Methods (LCA) have become increasingly important, although the use of assessment factors based on this method is limited (Parikka-Alhola and Nisinen, 2012).

Being the largest buyer in a country, the government has a significant influence on stimulating the use of green products and services in that country (Walker and Brammer, 2009).

The government is in a position to influence the demand for "environmentally friendly" products and can encourage businesses that involve green activities. (Buniamin et al., 2016).

Public authorities are major consumers in Europe: they spend about 1.8 trillion Euros each year, which represents about $14 \%$ of the European Union's GDP. By using their purchasing power, public authorities can choose to purchase products and services with a low environmental impact, thus contributing to sustainable production and consumption. (European Commission, 2016b).

With the adoption of the new European Public Procurement Directives in 2014 for several categories of products, including motor vehicles, contracting authorities should consider energy / fuel consumption and the environmental impact of motor vehicles in the procurement process through life-cycle costing (European Commission, 2016a).
Regarding the green public procurement in Romania in 2018, the National Agency for Public Procurement (A.N.A.P.) issued Order no. 1068/ 04.10.2018 for the approval of the Green Public Procurement Guidelines. This order contains the minimum environmental protection requirements for certain groups of products and services that are requested from the bidders according to the tender specifications.

The purpose of these guidelines is to provide contracting authorities with minimum mandatory environmental protection requirements to be considered when developing the Green Public Procurement Documents. Through this guide for transport vehicles, the minimum requirements for environmental protection are $\mathrm{CO} 2$ emissions and pollution standard (Euro VI).

\section{Study on the life cycle cost analysis on green public procurement of coaches in Romania}

The award criteria established by Law no. 98/2016 for a public procurement are the following: "lowest cost", "lowest price", "best cost-quality ratio" and "best pricequality ratio".

In green public procurement, most of the time the life cycle cost is a more relevant element to consider compared to the purchase price. There are products that, even if they have a low purchase price, they have higher operating and maintenance costs over the life cycle.

Some of my past research has shown that the life cycle cost is not always more relevant than the purchase price, and there are also cases where some products have the lowest purchase price but also the lowest life cycle cost.

In this study, we analysed the purchasing and life cycle costs for three representative coach models on the Romanian market, namely: Iveco Evadys, Mercedes-Benz Tourismo RH and Neoplan Tourliner. All three coach models meet the Euro VI pollution standard with low fuel consumption, thus complying with existing European environmental regulations. 
The main expenses required for purchasing, operating and dismantling a coach in accordance with the public road traffic legislation are:

- $\quad$ purchase price;

- operating expenses that consist of:

$$
\begin{aligned}
& \text { RCA insurance type } \\
& \text { (compulsory car insurance); } \\
& \text { (optional insurance); } \\
& \text { insurance } \\
& \text { inspections - ITP; } \\
& >\quad \text { periodical } \\
& \text { fuel costs; }
\end{aligned}
$$

$>\quad$ administrative charges

related to public road traffic;

- maintenance costs that consist of:

$>$ annual technical inspections;

$>$ current repairs (after the warranty period, excluding consumables);

$>$ cost of tires:

$>$ various maintenance costs;

- resale price after the exploitation period.

The purchase prices for the three standard coach models are shown in Table 1.

Table 1: Purchase prices for coach brands Iveco Evadys, Mercedes-Benz Tourismo RH and Neoplan Tourliner

\begin{tabular}{|c|c|}
\hline Brand and coach type & $\begin{array}{c}\text { Purchase price } \\
\text { (euro, excluding VAT) }\end{array}$ \\
\hline Iveco Evadys & 220,000 \\
\hline Mercedes Benz Tourismo RH & 245,000 \\
\hline Neoplan Tourliner & 240,000 \\
\hline
\end{tabular}

Sources: http://www.ivecocr.cz/en/article/evadys/prices, Retrieved on February 2, 2019; http://www.mercedes-benz-bus.com/ro_RO/buy/prices, Retrieved on February 3, 2019;

http://www.neoplan.com/global/en/coaches/tourliner-overview/prices, Retrieved on February 2, 2019

The main common technical features of the three types of coaches are detailed in Table 2.

Table 2: Technical characteristics of the three brands of coaches Iveco Evadys, MercedesBenz Tourismo RH and Neoplan Tourliner

\begin{tabular}{|c|c|c|c|c|}
\hline No. & Technical characteristics & Iveco Evadys & $\begin{array}{c}\text { Mercedes- } \\
\text { Benz } \\
\text { Tourismo RH }\end{array}$ & $\begin{array}{c}\text { Neoplan } \\
\text { Tourliner }\end{array}$ \\
\hline 1 & Length & $12.9 \mathrm{~m}$ & $13.1 \mathrm{~m}$ & $13.1 \mathrm{~m}$ \\
\hline 2 & Width & $2.55 \mathrm{~m}$ & $2.55 \mathrm{~m}$ & $2.55 \mathrm{~m}$ \\
\hline 3 & Height & $3.46 \mathrm{~m}$ & $3.68 \mathrm{~m}$ & $3.87 \mathrm{~m}$ \\
\hline 4 & Wheelbase & $7.06 \mathrm{~m}$ & $6.9 \mathrm{~m}$ & $7.05 \mathrm{~m}$ \\
\hline 5 & Gross vehicle weight rating & $19 \mathrm{t}$ & $19.5 \mathrm{t}$ & $19.5 \mathrm{t}$ \\
\hline 6 & Engine type & Cursor 9 & $0 \mathrm{M} \mathrm{936}$ & MAN D2676 \\
\hline 7 & Pollution standard & Euro VI & Euro VI & Euro VI \\
\hline 8 & Cylinder capacity & $8.7 \mathrm{l}$ & $7.7 \mathrm{l}$ & $12.4 \mathrm{l}$ \\
\hline 9 & Horsepower & $294 \mathrm{~kW}$ & $260 \mathrm{~kW}$ & $309 \mathrm{~kW}$ \\
\hline 10 & Torque & $(400 \mathrm{CP})$ & $(348 \mathrm{CP})$ & $(414 \mathrm{CP})$ \\
\hline 11 & Fuel tank capacity /ad-blue & $430 \mathrm{l} / 50 \mathrm{l}$ & $480 \mathrm{l} / 40 \mathrm{l}$ & $550 \mathrm{l} / 50 \mathrm{l}$ \\
\hline 12 & Fuel consumption & $26 \mathrm{l} / 100 \mathrm{~km}$ & $24 \mathrm{l} / 100 \mathrm{~km}$ & $32 \mathrm{l} / 100 \mathrm{~km}$ \\
\hline 13 & Tire size & $295 / 80 / \mathrm{R} 22.5$ & $295 / 80 / \mathrm{R} 22.5$ & $295 / 80 / \mathrm{R} 22.5$ \\
\hline
\end{tabular}

Ionel PREDA and Doina I. POPESCU (2019), Journal of Eastern Europe Research in Business and Economics, DOI: 10.5171/2019.139043 


\begin{tabular}{|l|c|c|c|c|}
\hline 14 & Number of passenger seats & 50 & 55 & 55 \\
\hline 15 & Outboard luggage volume & $10.2 \mathrm{~m}^{3}$ & $12.1 \mathrm{~m}^{3}$ & $12 \mathrm{~m}^{3}$ \\
\hline 16 & Volume of inner luggage & $1.8 \mathrm{~m}^{3}$ & $1.6 \mathrm{~m}^{3}$ & $1.8 \mathrm{~m}^{3}$ \\
\hline
\end{tabular}

Sources: vehicles identity cards and the following sites http://www.ivecocr.cz/en/article/evadys, Retrieved on January 9, 2019; http://www.mercedes-benz-bus.com/ro_RO/buy/services-online/download-technicalbrochures, Retrieved on January 16, 2019; http://www.neoplan.com/global/en/coaches/tourliner-overview, Retrieved on January 16, 2019

The average distance a coach runs per month is approximately $10,000 \mathrm{~km}$, and its lifespan is 5 years, therefore at the end of their life-cycle they must have run for about:

$10,000 \mathrm{~km} /$ month $\times 60$ months $=600,000 \mathrm{~km}$

The warranty period for new coaches is of 2 years or $100,000 \mathrm{~km}$. Based on the above estimation, any of the three coaches are under warranty for a period of 10 months.
The operating and maintenance costs taken into account are as follows:

- $\quad$ RCA insurance cost (compulsory car insurance)

According to the current Romanian legislation, a compulsory insurance policy is required to travel on public roads. The estimated costs of the RCA type insurance for the analysed coaches, classified as insurance class B0, are shown in Table 3.

Table 3: RCA type insurance costs

\begin{tabular}{|c|c|c|c|}
\hline Type of coach & $\begin{array}{c}\text { Iveco } \\
\text { Evadys }\end{array}$ & $\begin{array}{c}\text { Mercedes-Benz } \\
\text { Tourismo RH }\end{array}$ & $\begin{array}{c}\text { Neoplan } \\
\text { Tourliner }\end{array}$ \\
\hline $\begin{array}{c}\text { Annual insurance cost } \\
\text { (euro, excluding VAT) }\end{array}$ & 1,350 & 1,400 & 1,600 \\
\hline RCA insurance cost over the life cycle & 6,750 & 7,000 & 8,000 \\
\hline
\end{tabular}

Source: https://asfromania.ro/informatii-publice/statistici/statistici-asigurari, Retrieved on January 21, 2019

- Cost of CASCO insurance (optional insurance)

The estimated costs of a CASCO insurance for the analysed coaches are shown in Table 4.

Table 4: Cost of CASCO insurance

\begin{tabular}{|c|c|c|c|}
\hline Type of coach & $\begin{array}{c}\text { Iveco } \\
\text { Evadys }\end{array}$ & $\begin{array}{c}\text { Mercedes-Benz } \\
\text { Tourismo RH }\end{array}$ & $\begin{array}{c}\text { Neoplan } \\
\text { Tourliner }\end{array}$ \\
\hline Annual insurance cost for CASCO & 7,600 & 8,700 & 8,800 \\
\hline $\begin{array}{c}\text { CASCO insurance cost over the life cycle } \\
\text { (euro, excluding VAT) }\end{array}$ & 38,000 & 43,500 & 44,000 \\
\hline
\end{tabular}

Source: https://asfromania.ro/informatii-publice/statistici/statistici-asigurari, Retrieved on January 21, 2019

- The cost of regular technical inspections - ITP

Coaches are vehicles intended for the transport of people and their technical inspections are required every six months. The current cost of a periodical technical inspection is $€ 40$, excluding VAT. Estimated costs of periodic technical inspections for coaches analysed are shown in Table 5. 
Table 5: Costs of regular technical inspections

\begin{tabular}{|c|c|c|c|}
\hline Type of coach & $\begin{array}{c}\text { Iveco } \\
\text { Evadys }\end{array}$ & $\begin{array}{c}\text { Mercedes-Benz } \\
\text { Tourismo RH }\end{array}$ & $\begin{array}{c}\text { Neoplan } \\
\text { Tourliner }\end{array}$ \\
\hline $\begin{array}{c}\text { Anual Cost - ITP } \\
\text { (euro, excluding VAT) }\end{array}$ & 80 & 80 & 80 \\
\hline $\begin{array}{c}\text { ITP Cost over the life cycle } \\
\text { (euro, excluding VAT) }\end{array}$ & 400 & 400 & 400 \\
\hline
\end{tabular}

Sources: http://www.ivecocr.cz/en/article/evadys/services, Retrieved on January 7, 2019; http://www.mercedes-benz-bus.com/ro_RO/buy/services, Retrieved on January 7, 2019; http://www.neoplan.com/global/en/coaches/services, Retrieved on January 8, 2019

\section{- Fuel costs}

The estimated costs of fuel for the analysed coaches are shown in Table 6. To compensate for price differences across the member states of transit, the average price of a liter of diesel is 1.10 euro, excluding VAT.

Table 6: Fuel costs

\begin{tabular}{|c|c|c|c|}
\hline Type of coach & $\begin{array}{c}\text { Iveco } \\
\text { Evadys }\end{array}$ & $\begin{array}{c}\text { Mercedes-Benz } \\
\text { Tourismo RH }\end{array}$ & $\begin{array}{c}\text { Neoplan } \\
\text { Tourliner }\end{array}$ \\
\hline Fuel consumption (l / 100 km) & 26 & 24 & 32 \\
\hline Number of km per year (km) & 120,000 & 120,000 & 120,000 \\
\hline Annual fuel consumption (l) & 31,200 & 28,800 & 38,400 \\
\hline $\begin{array}{c}\text { Annual fuel consumption cost } \\
\text { (euro, excluding VAT) }\end{array}$ & 34,320 & 31,680 & 42,240 \\
\hline Cost of fuel over the lifecycle & 171,600 & 158,400 & 211,200 \\
\hline
\end{tabular}

Source: http://www.insse.ro/cms/ro/tags/buletin-statistic-de-preturi, Retrieved on January 19, 2019

- The cost of administrative charges on public roads

In order to travel on public roads, according to the legislation in force in Romania and the legislation in the European Community space it is necessary to pay various fees or charges for the transit of roads or motorways. The fees are the same for the three types of coaches compared, on average 70 euro, excluding VAT, for each transit country and 500 euro, excluding VAT, for Romania (validity 12 months, ie about 42 euro excluding VAT / month) Source: transit fees in Romania and the EU. On average, each coach crosses 5 countries, 4 times a month, for which the necessary charges will be calculated. Estimated costs with the administrative fees are shown in Table 7.

Table 7: Costs with administrative charges

\begin{tabular}{|c|c|c|c|c|c|c|}
\hline Romania & Country 1 & Country 2 & Country 3 & Country 4 & Country 5 & \multirow{2}{*}{$\begin{array}{c}\text { Annual costs with } \\
\text { administrative charges } \\
\text { (euro, exclusing VAT) }\end{array}$} \\
\hline $\begin{array}{l}\text { euro/ } \\
\text { Month }\end{array}$ & $\begin{array}{l}\text { euro/ } \\
\text { Transit }\end{array}$ & $\begin{array}{l}\text { euro/ } \\
\text { Transit }\end{array}$ & $\begin{array}{l}\text { euro/ } \\
\text { Transit }\end{array}$ & $\begin{array}{l}\text { euro/ } \\
\text { Transit }\end{array}$ & $\begin{array}{l}\text { euro/ } \\
\text { Transit }\end{array}$ & \\
\hline 42 & 70 & 70 & 70 & 70 & 70 & 18,816 \\
\hline \multicolumn{6}{|c|}{$\begin{array}{c}\text { Costs with administrative charges per life cycle } \\
\text { (euro, excluding VAT) }\end{array}$} & 94,080 \\
\hline
\end{tabular}

Source: Authors' conception 


\section{- Cost of technical inspections}

According to the manufacturers, technical inspections for the three types of coaches are carried out every $80,000 \mathrm{~km}$ or once a year, depending on the first criterion achieved, technical being performed both during the warranty period and postwarranty period. Estimated costs for technical inspections are shown in Table 8.

Table 8: Cost of technical inspections

\begin{tabular}{|c|c|c|c|c|c|c|}
\hline Type of coach & \multicolumn{2}{|c|}{$\begin{array}{c}\text { Annual } \\
\text { technical } \\
\text { inspection or } \\
\text { every } 80.000 \\
\text { km } \\
\text { (euro, } \\
\text { excluding } \\
\text { VAT) } \\
\end{array}$} & $\begin{array}{l}\text { Every } 6 \text { months } \\
\text { (includes } \\
\text { checking / } \\
\text { charging air } \\
\text { conditioning } \\
\text { system) } \\
\text { (euro, excluding } \\
\text { VAT) }\end{array}$ & \multicolumn{2}{|c|}{$\begin{array}{c}\text { Replacing } \\
\text { differential oil, } \\
\text { gearbox and } \\
\text { retarder } \\
\text { (every } 2 \text { years) } \\
\text { (euro, excluding } \\
\text { VAT) }\end{array}$} & $\begin{array}{c}\text { Total cost of } \\
\text { technical } \\
\text { inspections } \\
\text { (euro, } \\
\text { excluding VAT) }\end{array}$ \\
\hline Iveco Evadys & \multicolumn{2}{|l|}{850} & 250 & \multicolumn{2}{|c|}{550} & 7,850 \\
\hline $\begin{array}{c}\text { Mercedes- } \\
\text { Benz Tourismo } \\
\text { RH }\end{array}$ & \multicolumn{2}{|l|}{711} & 210 & \multicolumn{2}{|c|}{500} & 6,655 \\
\hline $\begin{array}{l}\text { Neoplan } \\
\text { Tourliner }\end{array}$ & \multicolumn{2}{|l|}{950} & 300 & \multicolumn{2}{|c|}{550} & 8,850 \\
\hline \multicolumn{7}{|c|}{ Amount allocated to technical inspections per operating year (euro, exclusing VAT) } \\
\hline Type of coach & Year 1 & Year 2 & Year 3 & Year 4 & Year 5 & $\begin{array}{c}\text { Total cost of } \\
\text { technical } \\
\text { inspections } \\
\text { (euro, } \\
\text { exclusing VAT) }\end{array}$ \\
\hline Iveco Evadys & 1,350 & 1,900 & 1,350 & 1,900 & 1,350 & 7,850 \\
\hline $\begin{array}{c}\text { Mercedes- } \\
\text { Benz Tourismo } \\
\text { RH } \\
\end{array}$ & 1,131 & 1,631 & 1,131 & 1,631 & 1,131 & 6,655 \\
\hline $\begin{array}{l}\text { Neoplan } \\
\text { Tourliner }\end{array}$ & 1,550 & 2,100 & 1,550 & 2,100 & 1,550 & 8,850 \\
\hline
\end{tabular}

Sources: http://www.ivecocr.cz/en/article/evadys/services, Retrieved on January 7, 2019; http://www.mercedes-benz-bus.com/ro_RO/buy/services, Retrieved on January 7, 2019;

http://www.neoplan.com/global/en/coaches/services, Retrieved on January 8, 2019

\section{- Cost of current repairs}

Current repairs include replacements of consumables both in warranty and post- warranty periods. Replacement of spare parts, checks and estimated costs of current repairs are shown in Table 9. 
Table 9: Cost with current repairs

\begin{tabular}{|c|c|c|c|c|c|c|c|c|c|}
\hline \multirow[b]{2}{*}{$\begin{array}{l}\text { Type of coach } \\
\text { /Benchmark }\end{array}$} & \multicolumn{3}{|c|}{ Iveco Evadys } & \multicolumn{3}{|c|}{ Mercedes-Benz Tourismo RH } & \multicolumn{3}{|c|}{ Neoplan Tourliner } \\
\hline & $\begin{array}{c}\text { No. } \\
\text { pieces }\end{array}$ & $\begin{array}{c}\text { Price per } \\
\text { unit } \\
\text { (euro, } \\
\text { excluding } \\
\text { TVA) }\end{array}$ & $\begin{array}{c}\text { Total } \\
\text { Value } \\
\text { (euro, } \\
\text { excluding } \\
\text { VAT) }\end{array}$ & $\begin{array}{c}\text { No. } \\
\text { Pieces }\end{array}$ & $\begin{array}{c}\text { Price per } \\
\text { unit } \\
\text { (euro, } \\
\text { excluding } \\
\text { VAT) }\end{array}$ & $\begin{array}{c}\text { Total } \\
\text { Value } \\
\text { (euro, } \\
\text { excluding } \\
\text { VAT) }\end{array}$ & $\begin{array}{c}\text { No. } \\
\text { pieces }\end{array}$ & $\begin{array}{c}\text { Price per } \\
\text { unit } \\
\text { (euro, } \\
\text { excluding } \\
\text { VAT) }\end{array}$ & $\begin{array}{c}\text { Total } \\
\text { Value } \\
\text { (euro, } \\
\text { excluding } \\
\text { VAT) }\end{array}$ \\
\hline $\begin{array}{l}\text { brake paddles } \\
\text { front axle }\end{array}$ & 6 & 310 & 1,860 & 6 & 350 & 2,100 & 6 & 400 & 2,400 \\
\hline $\begin{array}{l}\text { rear brake pad } \\
\text { plates }\end{array}$ & 6 & 200 & 1,200 & 6 & 300 & 1,800 & 6 & 350 & 2,100 \\
\hline $\begin{array}{l}\text { brake discs front } \\
\text { axle }\end{array}$ & 3 & 650 & 1,950 & 3 & 650 & 1,950 & 3 & 700 & 2,100 \\
\hline $\begin{array}{l}\text { brake discs rear } \\
\text { axle }\end{array}$ & 3 & 1,200 & 3,600 & 3 & 1,100 & 3,300 & 3 & 900 & 2,700 \\
\hline valve 4 ways & 1 & 450 & 450 & 1 & 550 & 550 & 1 & 400 & 400 \\
\hline clutch set & 1 & 1,700 & 1,700 & 1 & 1,550 & 1,550 & 1 & 1,700 & 1,700 \\
\hline head bar head & 1 & 150 & 150 & 1 & 200 & 200 & 1 & 200 & 200 \\
\hline various bulbs & 1 & 50 & 50 & 1 & 50 & 50 & 1 & 50 & 50 \\
\hline $\begin{array}{l}\text { set front axle } \\
\text { cushion set }\end{array}$ & 1 & 1,100 & 1,100 & 1 & 1,300 & 1,300 & 1 & 1,100 & 1,100 \\
\hline wheel geometry & 1 & 80 & 80 & 1 & 170 & 170 & 1 & 200 & 200 \\
\hline $\begin{array}{l}\text { Total cost of } \\
\text { current repairs } \\
\text { (euro, excluding } \\
\text { VAT) }\end{array}$ & - & - & 12,140 & - & - & 12,970 & - & - & 12,950 \\
\hline $\begin{array}{l}\text { Annual cost of } \\
\text { current repairs } \\
\text { (euro, excluding } \\
\text { VAT) }\end{array}$ & - & - & 2,428 & - & - & 2,594 & - & - & 2,590 \\
\hline
\end{tabular}

Sources: http://www.ivecocr.cz/en/article/evadys/services, Retrieved on January 7, 2019;

http://www.mercedes-benz-bus.com/ro_RO/buy/services, Retrieved on January 7, 2019;

http://www.neoplan.com/global/en/coaches/services, Retrieved on January 8, 2019

\section{- Cost of tyres}

The tires of the analysed coaches are used predominantly extra-urban, their average operational life being 5 years or $50,000 \mathrm{~km}$. The average price of a medium-size tire is 260 euro excluding VAT. Since the three compared coaches are equipped with tires of the same type and size, the cost is the same as follows:

Table 10: Annual cost of tires

\begin{tabular}{|c|c|c|c|c|c|}
\hline \multicolumn{4}{|c|}{ Annual cost of tires (euro, excluding VAT) } & \multirow{2}{*}{$\begin{array}{c}\text { Annual cost of tires } \\
\text { (euro excluding VAT) }\end{array}$} \\
\cline { 1 - 4 } Year 1 & Year 2 & Year 3 & Year 4 & Year 5 & 18,720 \\
\hline 3,120 & 3,120 & 4,680 & 3,120 & 4,680 & (20 \\
\hline
\end{tabular}

Sources: http://www.dinamic92.ro/anvelope/category.php?id_category=71646, Retrieved on January 11, 2019; https://www.anveloshop.ro/anvelope-autobuze-autocare, Retrieved on January 12, 2019; https://premiumanvelope.ro/118-anvelope-29580-r225-cauciucuri-295-80-225, Retrieved on January 11, 2019

Ionel PREDA and Doina I. POPESCU (2019), Journal of Eastern Europe Research in Business and Economics, DOI: $10.5171 / 2019.139043$
( 6 tires x 260 euro excluding VAT) x 12 sets $=18,720$ euro excluding VAT / life cycle

Taking into account the fact that tire replacement is carried out every $50,000 \mathrm{~km}$ and coaches run $120,000 \mathrm{~km} /$ year, we have the following annual costs of tires (Table 10). 


\section{Different maintenance costs}

During the operation of coaches, there are other maintenance costs to be considered, such as tachograph calibrations, wheel pressure checks, coach washes, oil and antifreeze refilling, cleaning solutions, etc. The maintenance costs are the same for the three types of coaches, their annual value being 350 euro, excluding VAT (Source: Average costs declared by Romania authorized dealers of coach manufacturers):

350 euro, excluding VAT x 5 years $=1,750$ euro excluding VAT / life cycle.

The legal provisions in force state that all annual costs related to the operation and maintenance of coaches will be taken into account in the life cycle cost calculation, then applying a discount rate for that year, so that all costs are calculated in the year of the purchase.

By the joint Order of the president of A.N.A.P. and the President of the National Prognosis Committee no.1170 / 2017, the discount rate used in 2018 for awarding contracts using the criteria "lowest cost" as the award criteria is $4.5 \%$.

The total operating and maintenance costs for the Iveco Evadys coach are detailed in Table 11. In this table, but also in tables 12 and 13 , the discount factor was calculated over the 5 years of operation according to formula $1 /(1+a)^{n}$, where a is the discount rate and $\mathrm{n}=1,2, \ldots, 5$.

Table 11: The total operating and maintenance costs for the Iveco Evadys coach

\begin{tabular}{|c|c|c|c|c|c|}
\hline Year / Cost (euro, excluding VAT) & $\mathbf{1}$ & $\mathbf{2}$ & $\mathbf{3}$ & $\mathbf{4}$ & $\mathbf{5}$ \\
\hline Cost of RCA insurance & 1,350 & 1,350 & 1,350 & 1,350 & 1,350 \\
\hline Cost of CASCO insurance & 7,600 & 7,600 & 7,600 & 7,600 & 7,600 \\
\hline Cost of regular technical inspections & 80 & 80 & 80 & 80 & 80 \\
\hline Cost of fuel & 34,320 & 34,320 & 34,320 & 34,320 & 34,320 \\
\hline Cost of administrative fees & 18,816 & 18,816 & 18,816 & 18,816 & 18,816 \\
\hline Cost of technical inspections & 1,350 & 1,900 & 1,350 & 1,900 & 1,350 \\
\hline Cost of current repairs & 2,428 & 2,428 & 2,428 & 2,428 & 2,428 \\
\hline Cost of tyres & 3,120 & 3,120 & 4,680 & 3,120 & 4,680 \\
\hline Cost of different maintenance expenses & 350 & 350 & 350 & 350 & 350 \\
\hline Operating and maintenance costs & 69,414 & 69,964 & 70,974 & 69,964 & 70,974 \\
\hline Discount rate for a = 4,5\% & 0.957 & 0.916 & 0.876 & 0.839 & 0.802 \\
\hline Updated operating and maintenance costs & 66,429 & 64,087 & 62,173 & 58,700 & 56,921 \\
\hline Total discounted operating and maintenance & & & $\mathbf{3 0 8 , 3 1 0}$ & & \\
\hline costs & & & & \\
\hline
\end{tabular}

Source: Authors' conception

The total discounted operating and maintenance costs for the Mercedes-Benz Tourismo RH coach are detailed in Table 12.

Table 12: The total discounted operating and maintenance costs for the Mercedes-Benz Tourismo RH coach

\begin{tabular}{|c|c|c|c|c|c|}
\hline Year / Cost (euro, excluding VAT) & $\mathbf{1}$ & $\mathbf{2}$ & $\mathbf{3}$ & $\mathbf{4}$ & $\mathbf{5}$ \\
\hline Cost of RCA insurance & 1,400 & 1,400 & 1,400 & 1,400 & 1,400 \\
\hline Cost of CASCO insurance & 8,700 & 8,700 & 8,700 & 8,700 & 8,700 \\
\hline Cost of regular technical inspections & 80 & 80 & 80 & 80 & 80 \\
\hline
\end{tabular}

Ionel PREDA and Doina I. POPESCU (2019), Journal of Eastern Europe Research in Business and Economics, DOI: 10.5171/2019.139043 


\begin{tabular}{|c|c|c|c|c|c|}
\hline Cost of fuel & 31,680 & 31,680 & 31,680 & 31,680 & 31,680 \\
\hline Cost of administrative fees & 18,816 & 18,816 & 18,816 & 18,816 & 18,816 \\
\hline Cost of technical inspections & 1,131 & 1,631 & 1,131 & 1,631 & 1,131 \\
\hline Cost of current repairs & 2,594 & 2,594 & 2,594 & 2,594 & 2,594 \\
\hline Cost of tyres & 3,120 & 3,120 & 4,680 & 3,120 & 4,680 \\
\hline Cost of different maintenance expenses & 350 & 350 & 350 & 350 & 350 \\
\hline Operating and maintenance costs & 67,871 & 68,371 & 69,431 & 68,371 & 69,431 \\
\hline Discount rate for $a=4,5 \%$ & 0.957 & 0.916 & 0.876 & 0.839 & 0.802 \\
\hline Cost de exploatare și întreținere actualizat & 64,953 & 62,628 & 60,822 & 57,363 & 55,684 \\
\hline Total discounted operating and maintenance costs & \multicolumn{5}{|c|}{301,449} \\
\hline
\end{tabular}

Source: Authors' conception

The total discounted operating and maintenance costs for Neoplan Tourliner are detailed in Table 13.

\section{Table 13: The total discounted operating and maintenance costs for the Neoplan Tourliner coach}

\begin{tabular}{|c|c|c|c|c|c|}
\hline Year / Cost (euro, excluding VAT) & 1 & 2 & 3 & 4 & 5 \\
\hline Cost of RCA insurance & 1,600 & 1,600 & 1,600 & 1,600 & 1,600 \\
\hline Cost of CASCO insurance & 8,800 & 8,800 & 8,800 & 8,800 & 8,800 \\
\hline Cost of regular technical inspections & 80 & 80 & 80 & 80 & 80 \\
\hline Cost of fuel & 42,240 & 42,240 & 42,240 & 42,240 & 42,240 \\
\hline Cost of administrative fees & 18,816 & 18,816 & 18,816 & 18,816 & 18,816 \\
\hline Cost of technical inspections & 1,550 & 2,100 & 1,550 & 2,100 & 1,550 \\
\hline Cost of current repairs & 2,590 & 2,590 & 2,590 & 2,590 & 2,590 \\
\hline Cost of tyres & 3,120 & 3,120 & 4,680 & 3,120 & 4,680 \\
\hline Cost of different maintenance expenses & 350 & 350 & 350 & 350 & 350 \\
\hline Operating and maintenance costs & 79,146 & 79,696 & 80,706 & 79,696 & 80,706 \\
\hline Discount rate for $\mathrm{a}=4,5 \%$ & 0.957 & 0.916 & 0.876 & 0.839 & 0.802 \\
\hline Updated operating and maintenance costs & 75,743 & 73,002 & 70,698 & 66,865 & 64,726 \\
\hline Total discounted operating and maintenance costs & \multicolumn{5}{|c|}{351,034} \\
\hline
\end{tabular}

Source: Authors' conception

\section{- $\quad$ Resale price after the exploitation period}

After studying the online sales sites in Romania, based on coach brand, model, age and number of kilometers, we found out that for each year of operation, the resale price dropped by an average of $14 \%$ for a properly maintained coach. At the end of its service life, the resale price is deducted from the lifetime cost as this value is received by the current owner of the coach from the next owner, following the completion of the sale-purchase process.

The resale prices after the exploitation period are shown in Table 14. 
Table 14: Resale price after the exploitation period

\begin{tabular}{|c|c|}
\hline Type of coach & $\begin{array}{c}\text { Resale price } \\
\text { (euro, excluding VAT) }\end{array}$ \\
\hline Iveco Evadys & 66,000 \\
\hline Mercedes Benz Tourismo RH & 73,500 \\
\hline Neoplan Tourliner & 72,000 \\
\hline
\end{tabular}

Sources: https://autoline.ro/-/autocare--c67, Retrieved on January 22, 2019;

http://www.autosupermarket.ro/ro/biggrid/O:Autobuze.html; https://www.europa-camioane.com/autocaresecond-hand/1-30/anunturi-autocare.html, Retrieved on January 22, 2019; http://www.depozitauto.ro/autocare/, Retrieved on January 24, 2019

Interpreting the results of the study on life cycle cost analysis of green public procurement of coaches in Romania

The main elements of the lifetime cost for the three coaches analysed, as well as the purchase prices, are presented in Table 15.

Table 15: Lifecycle costs and purchase prices for Iveco Evadys, Mercedes-Benz Tourismo RH and Neoplan Tourliner coaches

\begin{tabular}{|c|l|c|c|c|}
\hline No. & Price/cost (euro, excluding VAT) & Iveco Evadys & $\begin{array}{c}\text { Mercedes- } \\
\text { Benz } \\
\text { Tourismo RH }\end{array}$ & $\begin{array}{c}\text { Neoplan } \\
\text { Tourliner }\end{array}$ \\
\hline 1 & Purchase price & $\mathbf{2 2 0 , 0 0 0}$ & $\mathbf{2 4 5 , 0 0 0}$ & $\mathbf{2 4 0 , 0 0 0}$ \\
\hline 2 & $\begin{array}{l}\text { Total discounted operating and } \\
\text { maintenance costs }\end{array}$ & 308,310 & 301,449 & 351,034 \\
\hline 3 & $\begin{array}{l}\text { Resale price after the exploitation } \\
\text { period }\end{array}$ & 66,000 & 73,500 & 72,000 \\
\hline \multicolumn{2}{|c|}{$\begin{array}{c}\text { Coach cost per life cycle } \\
\text { (euro, excluding VAT) }\end{array}$} & $\mathbf{4 6 2 , 3 1 0}$ & $\mathbf{4 7 2 , 9 4 9}$ & $\mathbf{5 1 9 , 0 3 4}$ \\
\hline
\end{tabular}

Source: Authors' conception

From the analysis of the data in the table above, it can be seen that if the award

procedure had been carried out using the "lowest price" award criteria, the ranking would be as shown in Table 16.

Table 16: Ranking for the "lowest price" award criteria

\begin{tabular}{|c|c|c|c|}
\hline $\begin{array}{c}\text { Award } \\
\text { criteria }\end{array}$ & Lowest price \\
\hline No. & Coach Brand & $\begin{array}{c}\text { Position in } \\
\text { Ranking }\end{array}$ & $\begin{array}{c}\text { Purchase Price } \\
\text { (euro, excluding } \\
\text { VAT) }\end{array}$ \\
\hline 1 & Iveco Evadys & $1^{\text {st }}$ place & 220,000 \\
\hline 2 & Neoplan Tourliner & $2^{\text {nd }}$ place & 240,000 \\
\hline 3 & Mercedes-Benz Tourismo RH & $3^{\text {rd }}$ place & 245,000 \\
\hline
\end{tabular}

Source: Authors' conception

If the award procedure had been carried out using the "lowest cost" award criteria, the ranking would be as shown in Table 17. 
Table 17: Ranking for the "lowest cost" award criteria

\begin{tabular}{|c|c|c|c|}
\hline $\begin{array}{c}\text { Award } \\
\text { criteria }\end{array}$ & \multicolumn{3}{|c|}{ Lowest cost } \\
\hline No. & Coach Brand & $\begin{array}{c}\text { Position in } \\
\text { Ranking }\end{array}$ & $\begin{array}{c}\text { Life cycle cost } \\
\text { (euro, excluding VAT) }\end{array}$ \\
\hline 1 & Iveco Evadys & $1^{\text {st }}$ place & 462,310 \\
\hline 2 & Mercedes-Benz Tourismo RH & $2^{\text {nd }}$ place & 472,949 \\
\hline 3 & Neoplan Tourliner & $3^{\text {rd }}$ place & 519,034 \\
\hline
\end{tabular}

Source: Authors' conception

The purchase prices and life cycle costs presented in Tables 16 and 17 are graphically represented in Figure 1.

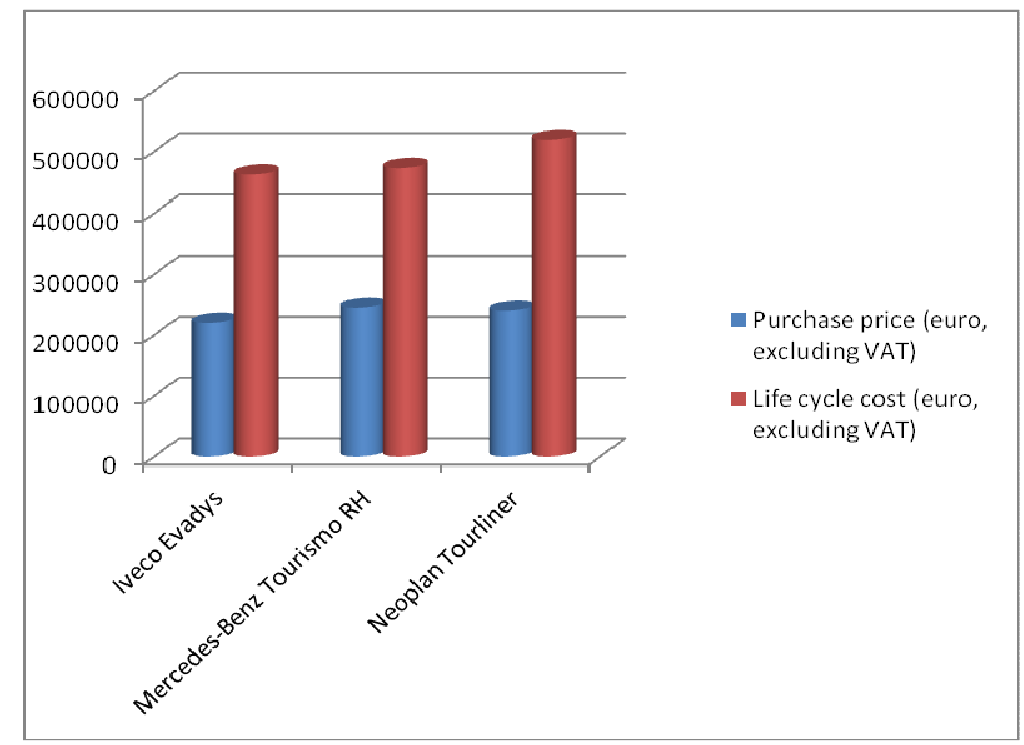

Figure 1: Graphic representation of purchase prices and life cycle costs

Source: Based on the data in Tables 16 and 17

It can be seen that the Iveco Evadys ranks

first both for the "lowest price" and the "lowest cost" award criteria.

In the study, it is clear that the Iveco Evadys model, both in terms of price and life cycle cost, would be the winner of the award procedure.

In contrast, for the other two models, namely Mercedes-Benz Tourismo RH and Neoplan Tourliner, the life cycle cost criteria is more relevant than the purchase price.

As a result, in the process of preparing the green procurement procedure to determine the award criteria, purchase prices need to be estimated and lifecycle costs have to be calculated for the most representative types of coaches on the market.

\section{Conclusions}

The article presents a comparative study on the acquisition of three types of coaches that are representative of the Romanian market, including a calculation of the life cycle costs and a comparison of the purchase rankings in case the award criteria would have been the lowest purchase price or the cost per smallest life cycle.

The study conducted has shown that Iveco Evadys coach model presents both the lowest price and the lowest life cycle cost. In contrast, in the case of the other two models, Mercedes-Benz Tourismo RH and Neoplan Tourliner, the study demonstrates the ranking of the procedure would have changed if the award criteria had been the 
lowest life cycle cost instead of the lowest purchase price.

In order to choose the most appropriate award criteria, before initiating the procedure, calculations should be performed on the basis of both the purchase price and the life cycle cost.

This analysis also shows that the life cycle cost is relevant when purchasing coaches. This conclusion is in line with part of the definition of green public procurement given by the E.U. and other authors.

\section{References}

1. Buniamin, S., Ahmad, N., Rauf, F., H., A, C., Johari, N., H., Rashid, A., A., (2016), 'Green Government Procurement Practices (GGP) in Malaysian Public Entreprises', 7th International Economics and Business Management Conference, $5^{\text {th }}$ and $6^{\text {th }}$ October 2015, 2, Elsevier

2. European Commission (2016a), 'Buying Green! A Handbook on Green Public Procurement', 3rd edition SEC, Brussels, Belgium, [Online], http://ec.europa.eu/environment/gpp/pdf/ Buying-Green-Handbook-3rd-Edition.pdf, Retrieved on december 26, 2018

3. European Commission, (2016b), 'Green Public Procurement', [Online], http://ec.europa.eu/environment/gpp/wha t_en.htm, Retrieved on december 26, 2018

4. Ghisetti, C., (2017), 'Demand-pull and environmental innovations: Estimating the effects of innovative public procurement', Technological Forecasting \& Social Change 125 (2017) 178 - 187, Elsevier

5. Parikka-Alhola, K., Nisinen, A., (2012), 'Environmental impacts and the most economically adventageous tender on public procurement', Journal of Public Procurement, 12(1), 43-80, cited în Vidal, R., Sanchez-Pantoja, N., (2019), 'Method based on life cycle assessment and TOPSIS to integrate environmental award criteria into green public procurement', Sustainable Cities and Society 44 (2019) 465-474, Elsevier

6. United Nations UN, (2015), 'Transforming our world: the 2030 Agenda for Sustainable Development', Resolution adopted by UN at 25 september 2015, [Online],

http://www.un.org/ga/search/view_doc.as p?symbol=A/RES/70/1\&Lang=E., Retrieved on december 25, 2018

7. Walker, H., Brammer, S., (2009), 'Sustainable procurement in United Kingdom public sector', Supply Chain Management: An International Journal, 14(2), 128-137 cited în Buniamin, S., Ahmad, N., Rauf, F., H., A, C., Johari, N., H., Rashid, A., A., (2016), 'Green Government Procurement Practices (GGP) in Malaysian Public Entreprises', 7th International Economics and Business Management Conference, $5^{\text {th }}$ and $6^{\text {th }}$ October 2015, Procedia Economics and Finance 35 ( 2016 ) 27 - 34, Elsevier

8. Witjes, S., Lozano, R., (2016), 'Towards a more Circular Economy: proposing a framework linking sustainable public procurement and sustainable business models'. Resour. Conserv. Recycl. 112, 37-44, cited în Aldenius, M., Khan, J., (2017), 'Strategic use of green public procurement in bus sector: Challenges and oportunities', Journal of Cleaner Production 164 (2017) 250-257, Elsevier 